\title{
Should the Common Buzzard be hunted?
}

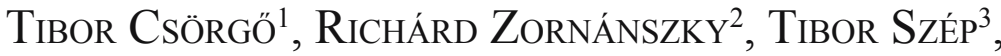 \\ PÉter FeHÉrvári ${ }^{4}$
}

Tibor Csörgö, Richárd Zornánszky, Tibor Szép, Péter Fehérvári 2012. Should the Common Buzzard be hunted? - Ornis Hungarica 20(2): 1-12.

Abstract The Common Buzzard is a widespread and abundant raptor in Europe. Recently, game keepers have argued that the buzzard population has increased in Hungary and is threatening valuable small game species. Hunting of the buzzard has been prohibited since 1933, and since 1954 it has also been protected by law, in Hungary. Here we review scientific literature on recent population changes of the species, prey composition, and anatomical constraints of foraging.

We show that according to the Common Bird Monitoring Program the breeding population remained stable in 1992-2012. Because of its anatomy and its hunting techniques it is not able to hunt efficiently for valuable small game. According to studies made with different methods in different parts of Europe in the last century, most of its prey species are small mammals. Therefore, the Common Buzzard population may help sustain rodent populations, thus providing essential ecosystem services for agriculture. Game species can also occur in the diet, however the proportion is negligible and buzzards usually acquire such prey as carcasses or handicapped individuals. We found no justification in favour of lifting the hunting ban of Common Buzzards in Hungary.

Keywords: population change, anatomy, foraging method, wildlife management, prey composition

Összefoglalás Az egerészölyv Európa egyik leggyakoribb ragadozó madara. A hazai állomány is jelentős, 10 ezres nagyságrendủ. 1933 óta élvez lelövési tilalmat, 1954 óta védett. Ennek ellenére az utóbbi években újra felmerült, hogy gyéríteni kellene a faj hazai állományát, mert annak nagysága jelentősen nött, ezért kártétele fokozódott.

Az MMM 1999-2012-es felmérései szerint a faj állománya ebben az időszakban stabil volt.

Anatómiai sajátosságai, vadásztechnikái miatt nem képes nagyobb testü, a vadgazdálkodásban érintett fajokat elejteni. Zsákmányállatainak nagyobb része - az utóbbi száz évben Európa különböző területein többféle módszerrel elvégzett vizsgálatok szerint - a mezőgazdaságban kártevő kisemlősökből kerül ki, amivel kimondottan nagy hasznot hajt. Mivel a táplálékmaradványokból ezek azonosítására kisebb az esély, mint a vadgazdálkodás szempontjából számbajöhető nagyobbakénak, ezek a számok még bizonyosan alá is becsülik az arányukat. A nagyobb testü állatok, vadgazdálkodás szempontjából hasznos fajok egyedei is szerepelhetnek az ölyv étlapján, de ezekhez legtöbbször az ember vagy valamely ügyesen vadászó ragadozó madár segítségével jut hozzá. Tevékenységük mindenképpen hasznosnak tekinthető, vadászatukat semmi nem indokolja.

Kulcsszavak: állományváltozás, anatómiai sajátosságok, vadásztechnikák, vadgazdálkodás, táplálékösszetétel

${ }^{1}$ Department of Anatomy, Cell and Developmental Biology, Eötvös Loránd University, 1117 Budapest, Pázmány Péter sétány 1/c, Hungary, e-mail: csorgo@elte.hu

${ }^{2}$ Department of Zoology and Animal Ecology, Szent István University, 2100 Gödöllö, Páter Károly utca 1., Hungary

${ }^{3}$ Institute of Environmental Sciences, College of Nyíregyháza, 4400 Nyíregyháza, Sóstói út 31/b, Hungary

${ }^{4}$ Department of Zoology, Hungarian Natural History Museum, 1088 Budapest, Baross utca 13., Hungary 


\section{Introduction}

The Common Buzzard (hereinafter: buzzard) is amongst the most abundant and widespread raptors in Europe. This species is divided into 6-8 distinct subspecies out of which the Hungarian population belongs to the subspecies $B . b$. buteo. Ring recoveries show that buzzards are predominantly resident in the Carpathian Basin, however a small proportion of birds may move to neighbouring southern countries for winter. The wintering population is also complemented with birds from Scandinavia and the Baltic Region (Tóth 2009, Saurola et al. 2013). The birds of the eastern subspecies (B. b. vulpinus) rarely migrate through Hungary (Hadarics \& Zalai 2008). Since 1933 the hunting of the buzzard has been prohibited, and since 1954 it has been protected by law (Haraszthy \& Bagyura 1983). Game keepers, farmers and other stakeholders recently raised the issue of lifting the protected status, thus legalizing hunting as a form of controlling buzzards. These stakeholders argue that the population has considerably increased in recent years and that these birds pose a serious risk for small game species with high economic value. This debate justified that BirdLife Hungary elected the species as the 'Bird of the year' in 2012 (http://www.mme.hu/component/content/ article/19-hirek-archivum/1395-a-joev-evegyik-eselyes-madara-segitseget-ker.html), raising wide public awareness of the issue.

Here we aim to review the international (British, Spanish, French, Danish, Norwegian, Polish, Czech, Slovak, Romanian) and Hungarian studies conducted on Common Buzzards in relation to this debate.

\section{Population change}

The European population increased between 1970 and 1990, then showed a slight decrease. At the turn of the century the estimated number of breeding pairs was 710 thousand. The species' status is evaluated as secure (BirdLife International 2004).

The Hungarian population of the species in recent decades of the last century - thanks to nature conservation legislation and public awareness - has increased (Haraszthy 2000). For instance in Békés county it went up to 150 pairs from 100 pairs between 1990 and 1995 (Tóth 1995 in Haraszthy 2000). At the turn of the century the breeding population was estimated to be between 10-20 thousand pairs (Hadarics \& Zalai 2008).

Based on representative countrywide sampling (Szép \& Nagy 2002), the Hungarian Common Bird Monitoring Program (MMM) estimated the population trends to be stable for 1999-2012 (Szép et al. 2013). The mean annual population change in this period (trend analysis, TRIM software package, Pannekoek \& van Strien 2001) did not show a significant increase or decrease (slope $=0.5 \%(\mathrm{SE}=1.1 \%)$ (Figure 1).

The National Game Management Database on the other hand shows a somewhat different trend; the numbers provided for these years are significantly higher, moreover they show a $50 \%$ increase. In the $2003-$ 2004 hunting season they estimated 62911 individuals, while in 2012-2013 this number was 96237 (http://www.ova.info.hu/vadgazdalkodasi_statisztikak.htm). The underlying reason in the deviation of the two estimates is the different applied methodology. The most obvious deviation is that the Common Birds Monitoring Program is a survey (i.e. systematic sampling of a population) while the National Game Management Database 


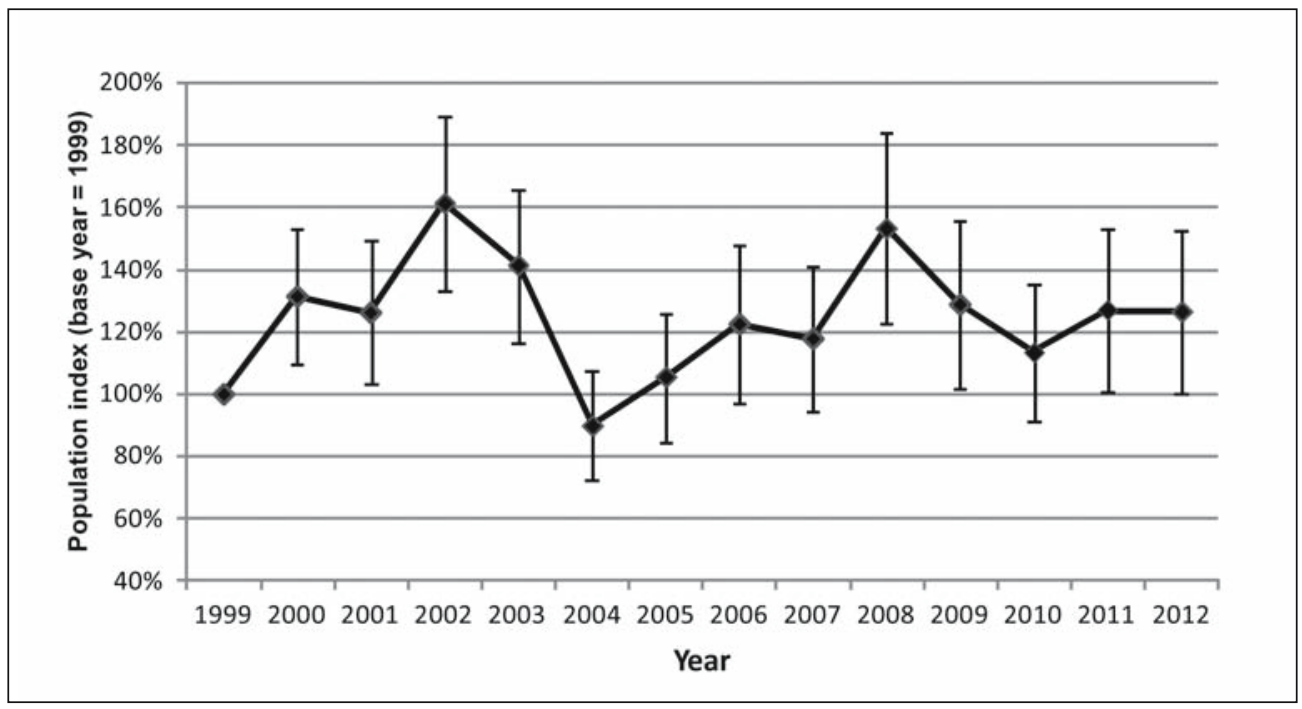

Figure 1. Population index of the Hungarian breeding population of the Common Buzzard according to data by the Common Bird Monitoring Program. The values of annual population indices and estimated indices SE are specified in comparison to the base year (1999)

1. ábra Az egerészölyv magyar fészkelő állományának változása az MME Mindennapi Madaraink Monitoringja (MMM) adatai alapján. Az éves populációs indexek (imputed index) és a becsült indexek SE értékei a bázis évhez (1999) viszonyítva vannak megadva

relies on a census (counting of all individuals of a population). Furthermore, there is a temporal difference between the two data series; the Common Bird Monitoring Program only uses data that derive strictly from the breeding season (http://www.mme-monitoring.hu/prog.php?datid=56) whereas the game management database only requests that data providers count the number of individuals present and presumably inhabiting the game management area, without any temporal restrictions (http://www.vmi. szie.hu/adattar/pdf/adatlapok-2013/becsles_terv-utmutato_2013.pdf).

The common bird census program estimates an average 30000 individuals (i.e. 15000 pairs) for the country. Typically clutch size is 2-4 eggs (Cramp \& Simmons 1980), however fledging success is considerably lower, only $0.42-2.13$ in the Swabian Alb (Rockenbauch 1975), in other regions of
Germany it is $0.42-2.17$, in the Pilis hills the estimated mean is 2.21 (Haraszthy \& Ott 1984), and in Békés county it is 1.2-2 (Tóth 1995 in Haraszthy 2000). In general, mean fledging success is less than 2 birds per nest. An indirect support of this general value is that the proportion of youngsters among observed birds is $31-51 \%$ in the Danish Strait every year (Forsman 2003). Returning to the potential number of buzzards in the Hungarian population; it is plausible that 50-55 thousand individuals may be present in the post-fledging period for a short time, but due to natural and human induced mortality (electrocution on medium voltage pylons, poisoning, illegal hunting etc.) this number certainly decreases by autumn and winter. According to ringing data the mortality rate of the birds in their first year is $46.4 \%$ (Germany), $65 \%$ (Sweden), 77.6\% (Great-Britain) (Cramp \& Simmons 1980). Furthermore, individuals 
from northern Europe also migrate through or overwinter within the Carpathian basin as suggested by ring recoveries, however assessing the ratio of resident vs. migrant buzzards is currently impossible.

An equally important deviation between the two datasets is that they are acquired on different spatial scales. The Common Bird Monitoring Program covers a smaller spatial extent as the sampling is carried out on a fraction of the total area of Hungary, although the sites and the observation points are randomly chosen, thus allowing statistically sound estimates. On the other hand the National Game Management Database holds information on the whole extent of Hungary, since all game management units are legally obliged to present data annually. However, the lack of defined methodology allows data providers to report numbers acquired with various techniques for each game management unit. Previously we have detailed that simply the timing of field observations within the season may remarkably influence the number of counted birds. Moreover, the game management database does not specify how to control for multiple counts of individuals, or for the spatial aggregation of individuals. Buzzards and other raptor species often aggregate in areas with high prey densities, like alfalfa fields or along large roads especially in winter. The reason for the latter is that road-kills are often consumed by buzzards, and also that roadside ditches are less likely to be influenced by rodenticides-but are often mowed- thus presenting larger densities of prey with high prey accessibility compared to other areas. A data provider may easily overestimate the number of buzzards present in the area based on observing these aggregations.

In the breeding season buzzards are territorial with variable territory sizes; in the Pilis hills between 1977 and 1981 the number of breeding pairs per $100 \mathrm{~km}^{2}$ varied between 40.8-437.3 annually, the territory of one pair was between 209-245 hectares (Haraszthy \& Ott 1983), on the Northern-Borsod-Karst on 30 thousand hectares 100-165 pairs bred between 1986 and 1991 (Varga \& Rékási 1993). This large variation may yield considerable estimation bias if not controlled for.

In summary, both methods have advantages and disadvantages, however when assessing the countrywide breeding population of buzzards, the Common Bird Monitoring Program offers a more valuable estimate compared to the National Game Management Database. Nonetheless, the demand for better understanding the breeding population size and trends of common diurnal raptors, MME/BirdLife Hungary launched a national Raptor Survey program that will hopefully allow an even more precise estimate of these figures in the future (http://www.mme-monitoring.hu/php/dl.php?drid=2971).

\section{Body structure and hunting method}

The body structure of the buzzard determines the spectrum of accessible prey species.

Its feet, toes and talons are comparatively shorter than the sympatric and similar sized Goshawk (Accipiter gentilis). This later species is considered to prey predominantly on birds (Widén 1987, Rutz \& Bjilsma 2006) in forest habitats and therefore is built for high maneuverability (Drennan \& Beier 2003). Buzzards however have broader wings and shorter tails and thus are less maneuverable in flight (Norberg 1995). They can only hunt prey with a maximum weight of 500 gramms, moving slowly on the ground, but since it is an opportunistic predator, the prey is typically much smaller (Cramp \& Simmons 1980). 
The predation of buzzards is characterized by three strategies. In most cases they perch and wait either on the ground or on a vantage point and drop themselves on the prey moving on the ground at a smaller distance. Buzzards can often be seen crouching on molehills or on the mounds of the Mound-building Mouse (Mus spicilegus). These individuals often do not even wait until their prey comes up to the surface, instead they catch them by grabbing the moving sloppy soil (Skoczen 1962, Kalotás 1980).

\section{Food}

During more than a century, many different methods have been used to analyze and observe the food of birds of prey. These include for example stomach content, pellet- and food remain analysis, observation, use of cameras (Vasvári 1930, Witherby et al. 1939, Glutz von Blotzheim et al. 1971, Brown 1976, Cramp \& Simmons 1980, Kostrzewa 2008). In general, food spectrum of buzzards varies with climate, thus the predominant prey species in different populations may be diverse along the breeding range. In most of the range the main prey species are small mammals, dominantly the Common Vole (Microtus arvalis). This is also proven by the fact that other than Hungarian, there are also many other languages where we can find the word mouse in the name of the species: German: Mäusebussard, Danish: Musvage, Icelandic: Músvákur, Norwegian: Musvak, Finnish: Hiirihaukka, Spanish: Ratonero Común, Polish: Myszolow, Slovak: Myšiaka Horneho (Sandberg 1992), Serbian: Mišar. In Great Britain where the Common Vole is not indigenous, the main prey species are birds, Rabbit (Oryctolagus cuniculus) Lepus species and Field Vole (Microtus agrestis)
(Tubbs 1967, Graham et al. 1995, Swann \& Etheridge 1995, Kenward et al. 2001). In Romania, the typical prey species are reptiles (Dombrowski 1912), while in Spain, beside reptiles also insects and Rabbits constitute bulk of the prey items (Palaus Soler 1960, Garzón Heydt 1974, Bustamante 1985, Mañosa \& Cordero 1992).

In some areas food composition can vary with season. This may also be true for even Mediterranean areas where inter-seasonal deviation of temperature is relatively low. The most abundant prey in the breeding period in Northeast Spain is the Rabbit. Buzzard breeding season coincides with, or is possibly timed to the emergence of juvenile Rabbits. The second most frequent prey are reptiles, dominantly Ocellated Lizard ( $L a-$ certa lepida). Also the importance of smaller birds became slightly stronger at this time of the year. This tendency was also supported by another investigation conducted in Spain (Bustamante 1985). Furthermore, the role of reptiles may be less pronounced in the colder season, however amphibians can appear in large numbers in their diet as species of this taxa tend to aggregate around at specific sites (Mañosa \& Cordero 1992).

Sex specific dietary differences are less pronounced compared to seasonal variation. In a study conducted in Spain the stomachs of males were empty more often, and smaller amphibians were found compared to females. Remains of bigger rabbits were only found in the stomachs of females. These differences were explained by reversed sexual dimorphism (Mañosa \& Cordero 1992). In contrast, other studies have not found significant sex specific differences in the diet in regards to the species and size of their prey (Bustamante 1985).

Prey composition may correlate with nestling size; smaller nestlings may receive 
smaller prey species (e.g. earthworms and voles), while larger nestlings are fed with more profitable prey like moles in a study conducted by Meier et al. (2000).

Studies have shown high individual differences in diet composition as well. For instance a male buzzard was observed to forage on Slow Worms (Anguis fragilis), Sand Lizards (Lacerta agilis), European Adders (Vipera berus), with only a single observation of vole as prey (Melde 1971). In contrast, Kalotás' (1985) observations suggest that Mole consumption of some buzzard pairs can reach $40-50 \%$.

Even though some individuals can be real specialists, the species is overall a generalist, its food is basically limited by food availability.

The most common prey of buzzards is the Common Vole in most parts of the European breeding range and thus the Carpathian Basin. According to a Slovakian study the Common Vole can reach up to $96 \%$ of the winter food composition (Salaj 1972). This vole species is active during the day and can reach high densities in arable fields where food abundance may be practically unlimited. Every few years it manifests itself in gradation. In other years their numbers can drastically drop, mainly due to climate factors (Gubányi \& Horváth 2007). In vole gradation years the proportion of the Common Vole in the prey composition is much bigger, than in normal or poor vole years (Mebs 1964, Kalotás 1985, Kostrzewa 2008).

The proportion of some animal groups can vary in the food composition depending on whether we take into consideration their weight or their relative frequency (Kostrzewa 2008). Despite this fact the proportion of the Common Vole is dominant both in vole gradation years and between these years according to both indices in a study in Poland. In vole gradation years the average frequency was $75 \%$, the weight proportion was $74 \%$, while in low vole years these numbers were $40 \%$ and $48 \%$. In these years the proportion of earthworms, insects and amphibians increased significantly while the proportion of other mammals increased insignificantly (Kostrzewa 2008).

Some buzzard pairs can be affected in different ways by different food availability. For some of them in the years when there is a lack of voles, the breeding can fail, or they lay fewer eggs. It can also occur that they interrupt breeding, in extreme situations; their nestlings starve to death depending on how the breeding and the period of the food shortage overlap with each other. As opposed to this, there are buzzard pairs, which raise nestlings, though less in low vole years. These shift food composition, the proportion of birds grows among prey animals (Kostrzewa 2008). The Mole can also be an alternative prey in Europe.

In studies conducted in Poland the Mole appeared in larger numbers, than the Common Vole (Czarneczki \& Foksowitz 1954). The food consisted of 50\% Moles and 33\% Common Voles. According to the age studies based on dentition analysis the proportion of juvenile Moles was $86,5 \%$ compared to other age groups in the whole sample. This is the result of the behaviour of young Moles in the start of their independent lives, in which the activity near the surface or even above the surface is very typical (Skoczen 1962).

In contrast to continental Europe, the dominant prey species in the British Isles are Rabbits, while alternative prey are Field Voles and birds (Graham et al. 1995).

Predators can react to the changes in prey abundance in two ways. Generalist species utilize alternative prey, while specialist species are less flexible hence their density 
changes. In case of the Common Buzzard, we can observe the combination of the two reactions (Reif et al. 2004).

According to the previous statements, the Common Buzzard can change its food, if the density of the preferred prey animal decreases, while there is a connection between the size of the vole population and the density of breeding pairs, clutch size and breeding success (Mebs 1964, Rockenbauch 1975, Reif et al. 2004).

According to a study conducted in Germany, the number of breeding pairs increased by $1 / 5$ in vole gradation years, compared to low vole years. In high voles years the ratio of the clutches with 3-4 eggs was 91\%, while in the low vole years this value decreased to $20 \%$. The breeding success (i.e. relative frequency of clutches that fledged) was $70.8 \%$, and $50 \%$, respectively (Mebs 1964). According to a study conducted in Finland, nesting rate (i.e. number of active nests / number of all territories) and its productivity (i.e. number of nestlings / number of all territories) positively correlated with the studied years' Microtus species density (Reif et al. 2004).

In none field vole mediated environments, the changes in densities of the main prey species show a similar correlation with buzzard reproductive success, in Great-Britain with the Rabbit (Moore 1957, Graham 1995, Swann \& Etheridge 1995), while in forest environment with the Bank Vole (Myodes glareolus) (Weber \& Stubbe 2000).

The population of buzzards depends not only on food availability, at least three other factors can play a part in the success of breeding. As buzzards breed in unsheltered twig-nests, the amount of rainfall in May is important. In rainy years the nestlings can get soaked, thus they may chill and die. In dry years fledging success is higher than in wet years. Other factors influencing reproductive success are interspecies competition and habitat quality. For instance, buzzards breeding in nests near Goshawk territories were less successful, because the Goshawks often carried away their nestlings. The more stable the breeding population is, the bigger the breeding success will be, and the bigger sight fidelity is typical for habitats optimal for the species (Kostrzewa \& Kostrzewa 1994). The number of breeding pairs is also controlled by intraspecies competition (Moore 1957, Cramp \& Simmons 1980, Newton \& Marquiss 1986 in Kostrzewa \& Kostrzewa 1994, Weber \& Stubbe 2000).

Among the winter weather factors, the temperature and the snow cover influence the survival just in extreme cases (Joensen 1968, Kostrzewa \& Kostrzewa 1991). If severe cold is accompanied by thick and permanent snow cover, they starve to death in large numbers (Mebs 1964).

Studies conducted in different parts of Europe (Rörig 1903, Dombrowski 1912, Uttendörfer 1952, Czarnecki \& Foksowicz 1954, Moore 1957, Sladek 1957, Toufar 1958, Palaus Soler 1960, Pinowski \& Ryszkovszki 1962, Skoczen 1962, Mebs 1964, Tubbs 1967, Joensen 1968, Thiollay 1968, Melde 1971, Salaj 1972, Ryszkovszki et al. 1973, Garzón Heydt 1974, Rockenbauch 1975, Bustamante 1985, Kostrzewa \& Kostrzewa 1991, 1994, Mañosa \& Cordero 1992, Graham et al. 1995, Swann \& Etheridge 1995, Meier et al. 2000, Weber \& Stubbe 2000, Kenward et al. 2001, Reif et al. 2004, Kostrzewa 2008), and also the inland studies (Nozdroviczky 1907, Barthos 1908, Greschik 1910, Bessenyei 1917, Greschik 1924, Tarján 1939, Kalotás 1980, 1982, 1983, 1985, Rékási 1981, Balogh \& Varga 1983, Varga 1984, Varga \& Rékási 1993, Fenyősi 1994, Bereczky 2010, Zornánszky et al. 2013) 
proved that the species eat primarily small rodents, dominantly Common Voles. From spring to autumn - in changing proportion insects and their larvas, amphibians, reptiles are also on its diet everywhere, and mainly in winter, when these prey animals are not accessible, it also eats different types of carrion for example fish (Toufar 1958, Sladek 1961, Kalotás 1982, 1985, Varga 1984). It can also capture fledglings or nestlings in small numbers (Glutz von Blotzheim et al. 1971, Salaj 1972, Kalotás 1985, Swann \& Etheridge 1995). Although according to some observations it attacks Hare (Lepus europaeus) (Nozdroviczky 1907, Bereczky 2010), Grey Partridge (Perdix perdix) (Bessenyei 1917) and Pheasant (Phasianus colchicus), but these are caught as youngsters or in an injured, weakened, sick state (Vasvári 1930, Glutz von Blotzheim et al. 1971).

Bigger animals, valuable game species can also be on the diet of buzzards, but in most cases these are obtained with the help of humans or other more skilful birds of prey (Uttendörfer 1952, Toufar 1958). It cannot cope with an adult Hare (Balogh \& Varga 1983).

The dominance of the main prey animals did not change, where they artificially raised and released Pheasants (Kalotás 1982, 1985, Kenward et al. 2001), or it is present naturally in high numbers (Rékási 1981).

According to studies conducted in the ' $80 \mathrm{~s}$, the Pheasants present in the diet of buzzards are from two large sources; a) from killed or injured birds, typically caused by mowers (Farkas 1977), and b) sick or poisoned birds (Farkas 1980).

Kalotás (1985) in 1981, during the peak of a vole gradation, could only prove one instance of buzzards foraging on Pheasants $(0.9 \%)$, but the Common Vole was present in $63.6 \%$ of the samples. In 1982, relatively often, in $38.5 \%$ of the cases the author found Pheasant remains in the stomachs of buzzards, but in half of these cases (15.4\%), it could be detected, that it was consumed while already dead, because the Pheasant remains were contaminated by fly larvae. In $19.2 \%$ of the samples he found the remains of Pheasants younger than 7 weeks. The relatively big occurrence of Pheasants can be the effect of the collapse of the Common Vole population after the gradation in 1981 . In 1982 altogether $34.6 \%$ was the proportion of the Common Vole in their diet.

In the southern part of Great-Britain they collected food remains from 40 nests, and followed the movement of 136 buzzards with radio telemetry with the aim of finding a connection between the rate of predation, the presence of buzzards, movement zone and the characteristics of the Pheasant pens. They found fresh Pheasant remains in $7 \%$ of the controlled nests. Only $8 \%$ of the radio-tagged buzzards had significantly more association than other buzzards with pens. The characteristics of the pens (small canopy coverage) and the release (lot of Pheasants in one pen) made it easy for the buzzards to catch them. The proportion of Pheasants of the diet was not more than 2.6\% (Kenward et al. 2001).

In general, dietary studies show that small rodents dominate both in proportion of weight and frequency of buzzard diet throughout the European breeding range. Smaller taxa are less likely to be discovered in dietary analyses, therefore the proportion of small mammals is probably even underestimated in these studies (Mebs 1964, Kalotás 1985, Graham et al. 1995, Kostrzewa 2008). In addition, the parents are likely to consume the smaller animals on the spot of the capture, and bring only the bigger ones to the nest (Mañosa \& Cordero 1992, Graham et al. 1995). The analysis of pellets also cannot 
give a perfect idea of the spectrum of prey animals, because the diurnal birds of prey digest most of the bones (Vasvári 1930, Uttendörfer 1952, Mebs 1964, Glutz von Blotzheim 1971, Kalotás 1982), the bigger ones are more likely to remain, so these are also overrepresented (Uttendörfer 1952). The bromatologyc analyses can only provide information on the prey caught directly before the shooting (Vasvári 1930). The use of mechanisms placed above the nest, collecting the prey animals dropped into the nest by the parents can give a more complete idea about the spectrum of prey animals and their proportion (Czarnecki \& Foksowicz 1954). Taking and analyzing of footage and pictures also do so (Meier 2000, Zornánszky et al. 2013), but probably the smaller prey animals are consumed by the parents more frequently than the bigger ones, because carrying them to the nest is more profitable.

In general, we found that the Hungarian breeding population of the buzzard is stable, and according to studies conducted with different methods in different areas and in different time periods throughout the past century, the proportion of valuable game species in the diet of buzzards is negligible. Presumably, this is caused by the fact that they are anatomically less capable of fora-

\section{References}

Balogh, L. \& Varga, Zs. 1983. Adatok a Sopron környéki egerészölyv- és héja-állomány ökológiájához [Data for the ecology of the Common Buzzard and the Goshawk population in the neighbourhood of Sopron]. - Tudományos Diákköri Dolgozat, Sopron [nyomtatott anyag] (In Hungarian)

Barthos, Gy. 1908. Néhány adat az egerészölyv táplálkozásához [Some data regarding the diet of the Common Buzzard]. - Aquila 15: 307-308. (In Hungarian)

Bereczky, A. Sz. 2010. Adatok az egerészölyv költésés táplálkozásbiológiájához [Data on the breeding biology and the food of the Common Buzzard]. ging on relatively large game species like Pheasants or Hares. The buzzards are most likely to catch sick, injured individuals (Vasvári 1930, Salaj 1962, Mebs 1964, Glutz von Blotzheim et al. 1971, Kalotás 1982), so their activity can be regarded even useful.

It was already stated a century ago - in a period with a completely different approach to birds of prey - that the agricultural benefit of buzzards surpasses the harm caused to game management (Greschik 1910, 1924, Toufar 1958, Salaj 1972, Kalotás 1980, 1982, 1983, 1985). Naturally the buzzards cannot abolish gradation, but can effectively participate in the reduction of the population's number (Ryszkowski et al. 1973).

The demand to control buzzard populations to reduce foraging pressure on game species is not substantiated based on our review of the vast literature cited in this paper. On the contrary, reducing the buzzard population would presumably result in less controlled Field Vole gradations.

\section{Acknowledgements}

We would like to express our gratitude to referees and Dániel Paizs, who made the language corrections for the paper.

- Heliaca 8: 91-92. (In Hungarian with English Summary)

Bessenyei, I. 1917. Adatok a vörös vércse, egerész ölyv és karvaly téli táplálkozásához [Data regarding the winter diet of Kestrel, Common Buzzard and Sparrowhawk]. - Aquila 24: 278. (In Hungarian)

BirdLife International 2004. Birds in Europe: population estimates, trends and conservation status. Cambridge, UK

Brown, L. H. 1976. British birds of prey. - Bloomsbury Books, London

Bustamante Díaz, J. M. 1985. Alimentacíón del ratonero común (Buteo buteo, L. 1758) en el norte de Es- 
paña [Food of the Buzzard (Buteo buteo, L. 1758) in the north of Spain]. - Doñana, Acta Vertebrata 12(1): 51-62. (In Spanish with English Summary)

Cramp, S. \& Simmons, K. E. L. 1980. Birds of Europe the Middle East and North Africa - The birds of the Western Palearctic. - Oxford University Press

Czarnecki, Z. \& Foksowicz, T. 1954. Obserwajce dotyczace skladu pokarmu myszolowa zwyczajnego (Buteo buteo L.) [Observations on the composition of the feed of Buzzard (Buteo buteo L.)]. - Ekologia Polska 2: 477-485. (In Polish with English Summary)

Dombrowski, R. 1912. Die Vogelwelt Rumanien's [The Birds of Romania]. - Bucharest (In German)

Drennan, J. E. \& Beier, P. 2003. Forest structure and prey abundance in winter habitat of Northern Goshawks. - The Journal of Wildlife Management 67(1): 177-185.

Farkas, D. 1977. A lucernabetakarítás hatása a mezeinyúlra és a fácánra [Effect of medick harvest on the Hare and the Pheasant]. - Nimród 17: 1-4. (In Hungarian)

Farkas, D. 1980. Azodrin 40 WSC üzemi vadtoxikológiai vizsgálata kelésben levő napraforgóban és kukoricában [Game toxicological study of Azodrin 40 WSC in sunflower and corn during sprouting]. - Növényvédelem 16(11): 564-566. (In Hungarian)

Fenyősi, L. 1994. Adatok az egerészölyv (Buteo buteo) táplálkozásához [Data regarding the diet of the Common Buzzard]. - Madártani Tájékoztató 1993-94. p. 17. (In Hungarian)

Forsman, D. 2003. The raptors of Europe and the Middle East. - Christopher Helm, London

Garzón Heydt, J. 1974. Contribución al estudio del status, alimentación y protección de las Falconiformes en Espana Central [Contribution to the study of the status, food and protection of Falconiformes in Central Spain]. - Ardeola 19: 279-330. (In Spanish with English Summary)

Glutz von Blotzheim, U. N., Bauer, K. M. \& Bezzel, E. 1971. Handbuch der Vögel Mitteleuropas 4. [Handbook of the Middle-European Birds 4.]. Akademische Verlagsgesellschaft, Frankfurt am Main (In German)

Graham, I. M., Redpath, S. M. \& Thirgood, S. J. 1995. The diet and breeding density of Common Buzzards Buteo buteo in relation to indices of prey abundance. - Bird Study 42(2): 165-173. doi:10.1080/00063659509477162

Greschik, J. 1910. Hazai ragadozómadaraink gyomor- és köpettartalom vizsgálata [Bromatologic and pellet analyses of birds of prey]. - Aquila 17: 168-179. (In Hungarian)

Greschik, J. 1924. Gyomor- és köpettartalom vizsgá- latok [Bromatologic and pellet analyses]. - Aquila 30-31: 243-263. (In Hungarian)

Gubányi, A. \& Horváth, Gy. 2007. Mezei pocok [Common Vole]. - In: Bihari, Z., Csorba, G. \& Heltai, M. (eds.) 2007. Magyarország emlőseinek atlasza [The atlas of Hungarian mammals]. - Kossuth Kiadó, Budapest pp. 162-163. (In Hungarian)

Hadarics, T. \& Zalai, T. (eds.) 2008. Nomenclator Avium Hungariae [An annotated list of the birds of Hungary]. - MME, Budapest (In Hungarian with English Summary)

Haraszthy, L. \& Bagyura, J. 1983. Ragadozómadár-védelem az elmúlt 100 évben [Protection of birds of prey in the last 100 years]. - Aquila 100: 105-225. (In Hungarian with English Summary)

Haraszthy, L. \& Ott, J. 1984. Egerészölyv (Buteo buteo) állomány vizsgálata a Pilis hegység területén 1977-1981 között [Study on the Buzzard stock (Buteo buteo) in the area of the Mountain Pilis, between 1977 and 1981]. - Puszta 10: 11-18. (In Hungarian with English Summary)

Haraszthy, L. (ed.) 2000. Egerészölyv [Common Buzzard]. - In: Haraszthy, L. 2000. Magyarország madarai [Birds in Hungary]. - Mezőgazda Kiadó, Budapest

Joensen, A. H. 1968. En undersogelse af ynglebestanden af Musvage pa Als 1962 pa 1963 [An investigation on the breeding population of the Buzzard (Buteo buteo) on the Island Als in 1962 and 1963]. - Dansk Ornitologisk Forening Tidsskrift 62: 1731. (In Danish with English Summary)

Kalotás, Zs. 1980. Eszi vagy nem eszi? [Does it eat or not?] - Nimród 20: 250-252. (In Hungarian)

Kalotás, Zs. 1982. Adatok az egerészölyv (Buteo buteo) táplálkozásához [Data regarding the diet of the Common Buzzard (Buteo buteo)]. - Állattani Közlemények 69: 111-117. (In Hungarian)

Kalotás, Zs. 1983. Az egerészölyvek (Buteo buteo) vadgazdálkodási szerepének vizsgálata apróvaddal dúsított vadászterületen [Study of the game management role of the Common Buzzard in a territory enriched with winged game]. - Puszta 10: 31-35. (In Hungarian with German Summary)

Kalotás, Zs. 1985. Újabb adatok az egerészölyv (Buteo buteo) táplálkozásához [New data on the food of Common Buzzard (Buteo buteo)]. - Állattani Közlemények 69: 85-93. (In Hungarian with English Summary)

Kenward, R. E., Hall, D. G, Walls, S. S. \& Hodder, K. H. 2001. Factors affecting predation by Buzzards Buteo buteo on released Pheasants Phasianus colchicus. - Journal of Applied Ecology 38: 813822. doi:10.1046/j.1365-2664.2001.00636.x

Kostrzewa, A. 2008. Nahrungswahl von Mäusebussard Buteo buteo und Habicht Accipiter gentilis - eine 
Metaanalyse rheinischer und europäischer Daten der letzten hundert Jahre [Food selection of Common Buzzards Buteo buteo and Goshawks Accipiter gentilis - a metaanalysis of data from Europe and Germany from the last one hundred years]. - Charadrius 44(1): 1-18. (In German with English Summary)

Kostrzewa, A. \& Kostrzewa, R. 1994. Population limitation in Buzzards Buteo buteo and Kestrels Falco tinnunculus: the different roles of habitat, food and weather. - Raptor Conservation Today WWGBP, Berlin pp. 39-48.

Kostrzewa, R. \& Kostrzewa, A. 1991. Winter weather, spring and summer density, and subsequent breeding success of Eurasian Kestrels, Common Buzzards and Northern Goshawks. - The Auk 108: 342-347.

Mañosa, S. \& Cordero, P. J. 1992. Seasonal and sexual variation in the diet of the Common Buzzard in Northeastern Spain. - Journal of Raptor Research 26(4): 235-238.

Mebs, T. 1964. Zur Biologie und Populationsdynamik des Mäusebussards (Buteo buteo) [About the biology and population dynamics of the Buzzard]. Journale für Ornithologie 105: 247-306. (In German with English Summary)

Meier, B., Stubbe, M. \& Fehlberg, U. 2000. Untersuchungen zur Nahrungsökologie des Mäusebussards (Buteo buteo) im Geestbereich Schleswig-Holsteins [Investigations on feeding ecology of the the Common Buzzard (Buteo buteo) in the geest area of Schleswig-Holstein]. - Populationsökologie Greifvogel und Eulenarten 4: 223-232. (In German with English Summary)

Melde, M. 1971. Der Mäusebussard [The Common Buzzard]. - Neue Brehm Bücherei, Wittenberg Lutherstadt (In German)

Norberga, U. M. 1995. Wing design and migratory flight. - Israel Journal of Zoology 41(3): 297-305. doi: 10.1080/00212210.1995.10688801

Nozdroviczky, L. 1907. A Buteo buteo (L.) nyúlvadászata [Hare hunting of Buteo buteo (L.)]. - Aquila 14: 319. (In Hungarian)

Palaus Soler, F. J. 1960 Notas ornitologicas del Noreste de España [Ornithologic notes of NortheastSpain]. - Ardeola 6: 222-233.

Pannekoek, J. \& van Strien, A. J. 2001. TRIM 3 Manual. Trends and indices for monitoring data. Research paper no. 0102.

Pinowski, J. \& Ryszkovszki, L. 1962. The Buzzard's versatility as a predator. - British Birds 55: 470-475.

Reif, V., Jungell, S., Korpimaki, E., Tornberg, R. \& Mykra, S. 2004. Numerical response of Common Buzzards and predation rate of main and alternative prey under fluctuating food conditions. - Annales Zoologici Fennici 41: 599-607.
Rékási, J. 1981. Adatok az egerészölyv táplálkozásához fiókanevelés idején [Data regarding the diet of the Common Buzzard in breeding time]. - Madártani Tájékoztató jan-febr-márc. pp. 232-233. (In Hungarian)

Rockenbauch, D. 1975. Zwölfjahrige Untersuchungen zur Ökologie des Mäusebussards (Buteo buteo) auf der Schwabischen Alb [12-year's study of the ecology of the buzzard in the Schwabische Alb]. Journal für Ornithologie 116: 39-54. (In German)

Rutz, C. \& Bijlsma, R. G. 2006. Food-limitation in a generalist predator. - Proceedings of the Royal Society B 22 273(1597): 2069-2076. doi:10.1098/ rspb.2006.3507

Ryszkowski, L., Goszczynski, J. \& Tuszkowski, J. 1973. Trophic relationship of the Common Vole in cultivated fields. - Acta Theriologica 18(7): 125-165.

Salaj, J. 1972. Potrava myšiaka horného (Buteo buteo) z oblastí Lučenca a Šiah r. 1956-1961. [Food of the Common Buzzards in the region of Lucenec and Sahy in the years 1956-1961]. - Biológia 17: 537-542. (In Slovak with German Summary)

Sandberg, R. 1992. European bird names. - Anser Suppliment 28, Lund

Saurola, P., Valkama, J. \& Velmala, W. 2013. Suomen Rengastusatlas 1. [The Finnish Bird Ringing Atlas 1.]. Luomus (In Finnish with English Summary)

Skoczen, S. 1962. Age structure of skulls of the Mole, Talpa europea Linnaeus 1758. from the food of the Buzzard (Buteo buteo L.). - Acta Theriologica 6(1): 1-9.

Sladek, J. 1961. Príspevok k poznaniu potravnej ekológie myišiaka lesného Buteo buteo (L.) [Data for the knowledge of the Buzzard's (Buteo buteo L.) food ecology]. - Zoologické Listy 10: 331-344. (In Slovak with German Summary)

Swann, R. L. \& Etheridge, B. 1995. A comparison of breeding success and prey of the Common Buzzard Buteo buteo in two areas of northern Scotland. - Bird Study 42(1): 37-43. doi:10.1080/ 00063659509477146

Szép, T. \& Nagy, K. 2002. Mindennapi Madaraink Monitoringja (MMM) 1999-2000 [Hungarian Common Bird Monitoring Program (MMM) 1999-2000]. - MME/BirdLife Hungary, Budapest (In Hungarian)

Szép, T., Nagy, K., Nagy, Zs. \& Halmos, G. 2013. Population trends of common breeding and wintering birds in Hungary, decline of long-distance migrant and farmland birds during 1999-2012. Ornis Hungarica 20(2): 13-63.

Tarján, T. 1939. Egérjárás és ragadozómadárgyülekezés [Mouse invasion and bird of prey assemblage]. - Aquila 42: 686. (In Hungarian) 
Thiollay, J. M. 1968. Régime alimentaire de nos rapaces: quelques analyses francaises [The diet of our birds of prey: some French analyses]. - Nos Oiseaux 29: 249-269. (In French)

Tóth, L. 1995. A Békés megyei ragadozómadár állomány helyzete és változásai 1990-1995. [Situation and changes of the population of birds of prey in Békés county]. - MME Kiadvány p. 55.

Tóth, L. 2009. Egerészölyv [Common Buzzard]. - In: Csörgő, T., Karcza, Zs., Halmos, G., Magyar, G., Gyurácz, J., Szép, T., Bankovics, A., Schmidt, A. \& Schmidt, E. (eds.) 2009. Magyar madárvonulási atlasz [Hungarian Bird Migration Atlas]. - Kossuth Kiadó, Budapest pp. 221-224. (In Hungarian with English Summary)

Toufar, J. 1958. Příspěvek k poznání potravy mladých kání lesních (Buteo buteo) podle zbytků koristi na hnízdec [For the knowledge of the food of the Common Buzzard nestlings]. - Sylvia 15: 67-76. (In Czech with German Summary)

Tubbs, C. R. 1967. Population study of Buzzards in the New Forest during 1962-66. - British Birds 60(10): 381-395.

Uttendörfer, O. 1952. Neue Ergebnisse über die Ernahrung der Greifvögel und Eulen [Newer results regarding the diet of birds of prey and owls]. Eugen Ulmer Stuttgart (In German with English Summary)

Varga, Zs. \& Rékási, J. 1993. Adatok az Észak-Borsodi Karszton fészkelő ragadozómadarak táplálkozásához és állományváltozásaihoz az 1986-1991 közötti időszakban [Food and population dynamics of birds of prey]. - Aquila 100: 123-136. (In Hungarian with English Summary)

Varga, Zs. 1984. Az egerészölyv és a héja ökológiájának vizsgálata Sopron környékén és a Börzsönyben [Study of the ecology of the Common Buz- zard and the Goshawk in the region of Sopron and in the Börzsöny]. - Diplomaterv Nyugat-magyarországi Egyetem, Sopron (In Hungarian)

Vasvári, M. 1930. Az egerészölyv és gatyásölyv táplálkozása [The diet of the Buzzard and the Rough-legged Buzzard]. - A természet 27: 281282. (In Hungarian)

Weber, M. \& Stubbe, M. 2000. Nahrungsangebot und Nahrungswahl von Rotmilan (Milvus milvus) und Mäusebussard (Buteo buteo) im nordöstlichen Harzvorland nach 1990 [Food supply and diet of Red Kite (Milvus milvus) and the Common Buzzard (Buteo buteo) in the northeastern Harz foreland after 1990]. - Populationsökologie Greifvogel und Eulenarten 4: 203-222. (In German with English Summary)

Widén, P. 1987. Goshawk predation during winter, spring and summer in a boreal forest area of central Sweden. - Ecography 10(2): 104-109. doi:10.1111/j.1600-0587.1987.tb00745.x

Witherby, H. F., Jourdain, F. C. R., Ticehurst, N. F. \& Tucker, B. W. 1939. The handbook of British birds 3. H. F. \& G. Withery LTD, London

Zornánszky, R., Pomichal, K., Molnár, I. L. \& Csörgő, T. 2013. Aktuális-e az egerészölyv vadászata? [Is the hunting of the Buzzard timely?] - 5. Szünzoológiai Szimpózium, Vácrátót (In Hungarian) http://www.mme.hu/component/content/article/19-hirek-archivum/1395-a-joev-ev-egyik-eselyes-madara-segitseget-ker.html http://www.mme-monitoring.hu/prog.php?datid=56 http://www.mme-monitoring.hu/php/ dl.php?drid $=2971$

http://www.ova.info.hu/vadgazdalkodasi_statisztikak. htm

http://www.vmi.szie.hu/adattar/pdf/adatlapok-2013/ becsles_terv-utmutato_2013.pdf 